\title{
HEURISTIC EVALUATION OF E-GOVERNMENT WEBSITES' USABILITY IN INDIA
}

\author{
SANDEEP KAUR $^{1 *} \&$ DR. M. SRIHARI ${ }^{2}$ \\ ${ }^{I}$ Assistant Professor and Ph.D Research Scholar, Department of Communication and Media Studies, Bharathiar University, \\ Coimbatore - 641046, Tamilnadu, India \\ ${ }^{2}$ Assistant Professor and Research Supervisor, Department of Communication and Media Studies, Bharathiar University, \\ Coimbatore - 641046, Tamilnadu, India
}

\begin{abstract}
Usability is the pinnacle of interface design with the manifestation of need-based Website Interface as its key component in E-government Websites. This paper evaluated the select E-government Websites in India through a comprehensive content analysis using heuristic evaluation to determine the nature of distribution of the ordinal population of variables that may complement and contribute to a pleasurable user experience.

Research Aim
\end{abstract}

An Expert-based Heuristic Evaluation perspective was proposed to evaluate Homepage considered as a prerequisite for the survival of E-government Websites. Through the constituent dimensions namely Online Services, User Help and Feedback, Navigation, Legitimacy, Information Architecture and Accessibility Accommodation, an attempt was made to principally demonstrate the implementation status of Usability in these Websites in India.

Theoretical Framework

Evaluation of E-government Website Usability primarily considered noticeable aspects of the ordinal structure of Usability dimensions germane to E-government Websites. The validated theoretical framework enhanced by Baker (2004) asserted the demand side strategic considerations in E-government development in India.

Methodological Framework

An Explanatory Research Design rigorously investigated the Homepage Usability of E-government Websites by logically interconnecting various methods and procedures. The Conceptual/Thematic Content Analysis of a wellformulated set of ordinal Usability heuristics evaluated E-government Websites and presented with intensity of variables along a continuum across six dimensions. A Usability Measurement Tool comprising 14 Usability heuristics with 56 scale measures was developed and applied to a cluster of 17 E-government Websites in India for examining the implementation status of its Usability.

Research Prerogative

The available literature cites poor Usability as one of the critical factors for continued failure of E-government services in developing countries. Hence, an Expert-based Heuristic Evaluation of Homepage becomes paramount to address the significant gap in E-government systems besieged by several Usability problems.

Research Implications

The prologue to select Usability heuristics for assessment of the nature of ordinality of variables on Homepage of select E-government Websites provide an analytical framework for addressing high Usability standards for users to maximize benefits from E-government Websites. The findings of this study have a potential significance that may aid 
in accelerating India's E-government development.

KEYWORDS: Interface Design-Usability-Other Digital Divide-Ease of Use-Heuristics-Ordinality.

Received: May 22, 2021; Accepted: Jun 12, 2021; Published: Jul 02, 2020; Paper Id.: IJCMSDEC20211

\section{INTRODUCTION}

User inconvenience with the ease of finding information ascribes the information seeking behavior in E-government Websites (Anderson, 2002) that leads to the other digital divide (Stowers, 2002). The resultant Usability barrier, thus, creates a gap between those having adequate knowledge of government and technology skills to access government websites and those having a deficient understanding about government and derisory technology expertise to access the same. Hence, both the digital user and E-government Websites' Usability signify the structural apparatus of the Information Society wherein the user interface complements the provision of multi-optional access to Information resources to meet the information needs of users. Consequently, an investigation into E-government Websites' capabilities become paramount in making it easier to use E-government websites for the stipulation of seamless access by Indian citizenry.

Based on the National e-Governance Service Delivery Assessment Framework (2019) conducted on the four parameters namely Accessibility, Content Availability, Ease of Use and Information Security and Privacy in select Egovernment Portals of Central Ministries, the following reveals notable aspects of the action plan for key assessment parameters:

- Provision of Accessibility through the availability of bilingual content, listing of contact information of government officials/agency providing online services, a separate 'Contact Us' page, an A to Z index as navigation routes, and downloadable forms.

- Content Availability via user feedback/comments, a separate section for help and Frequently Asked Questions (FAQs), availability of Sitemap, and information on last updated time-stamp.

- Ease of Use in terms of provision of downloadable application forms, availability of online services within 2clicks from Homepage, provision of a 'What's New' feature, and search feature.

- Information Security and Privacy reflected through the visible security policy of the Government, and Clear indication of $\mathrm{W} 3 \mathrm{C}$ Compliance of the webpage on the Homepage

Moreover, the E-government progress recognizes the efforts taken by the country to attain the $100^{\text {th }}$ position up from 96 in 2018 (UN Survey, 2020) that depict the influence of digital technologies on India's advancement in Egovernment development. Contextually, user engagement with E-government Websites enfolds a well-organized information structure with adequate navigation cues to facilitate access and use of online services with self-help instructions and protection of personal information for endorsing Information Needs as asserted by Patterson and Ellis (2004). 


\section{THEORETICAL FRAMEWORK FOR E-GOVERNMENT WEBSITE USABILITY}

This paper situates the Six Dimensional Usability as a frame of reference for the research problem and suitable analysis of data for accomplishing consequential and generalizable outcomes. Consequently appropriated are the strategic considerations that determine and comprehend the following Usability determinants germane to E-government Websites that become an imperative critical research area for addressing the probabilistic causal relation between Usability and continued failure of E-government initiatives in developing countries:

\subsection{Online Service}

Baker (2009) defines Online Service as a task that users can complete electronically via an E-government Website 24/7 using the internet. Therefore, the availability of the type and number of services premeditate both the content and information value for user-task completion in E-government Websites (ibid). This signifies the decisive role of the overall user experience in the diffusion of E-government with user-centric services. Various factors such as multilingualism (Bouaziz \& Fakhfakh, 2007), locally relevant content in native (Parasuraman et al., 2005; Kim et al., 2006), online demos and trials along with voice aid (Sarkar \& Cybulski, 2004), opinion poll system, message board and social media platform (Cox \& Dale, 2001; Liu \& Arnett, 2000; Yang et al., 2005), authentic and updated content, availability of comprehensive contact information (Email, postal address and/or the telephone/fax numbers) (UNESCO, 2005), and scannable text (Nielsen, 1999) considerably maximize user engagement.

\subsection{User Help and Feedback}

Provision of adequate helpful information in E-Government Website helps novice users' engagement with the timely access to government information and services. As E-government Websites contain enormous data, a manifest online help function on all web pages (Huang \& Benyoucef, 2014) and the search functionality with helpful clues that support user searches (Venkatesh et al., 2014) determines a usable and accessible E-government Website. In addition, the provision of Frequently Asked Questions (FAQs) assist users in expedient retrieval of vital information (Koyani, 2001) while contact details of the officials and support staff help in handling queries with minimum response time (Kim \& Stoel, 2004; Zeithaml et al., 2000). The availability of the above said trounces any discomfort prompted among users to resolve issues encountered while maneuvering these websites.

\subsection{Navigation}

The Information Foraging (Pirolli \& Card, 1999) developed as cognitive models of Web navigation predicts Website Usability through perceptual cues that users associate with links from one web page to another (Pirolli, 2003) to comprehend the information value of the content. Hence, the creation of good links and navigation mechanisms provide users with their location on a web page (Mandel, 1997; Baker, 2009; Bishop, Shuman \& Vodnik, 2015; Nielsen \& Pernice, 2010) as quicker routes to access the required services (Stowers, 2002). Contrarily, inadequate consideration of Navigation in the website design process challenges the survival of E-government websites (Zhao \& Benyoucef, 2014).

\subsection{Legitimacy}

In accordance with Stowers (2002), the Legitimacy characteristics reassure users of the E-government Websites with security and authenticity in service access. Besides, several features endow with credible evidence and legitimize an EGovernment Website as an official venue for seeking service from a particular governmental entity. These include well- 
worded disclaimers, privacy policies, terms and conditions, and copyright information (Asiimwe \& Lim, 2010). Additionally, the site address or the URL is considered an equally significant aspect related to the credibility of Egovernment website (UNESCO, 2005). Contact details increase the legitimacy of the information that the website contains (Nielsen \& Tahir, 2002).

\subsection{Information Architecture}

The availability and accessibility of information fabricates a citadel of sophisticated comprehension among users through the Information Architecture (IA) of E-government Websites. The IA defines the relationship between a website's content and its functionality (Cardello, 2014) and encourages ease of use that significantly influences E-government adoption. Through the effective design, the ease of understanding the system often provides psycho-pleasure to users by ambiguity resolution, attitude formation, agenda setting, expansion of belief system, and value clarification in quickly finding the information restricted onto web pages to resolve equivocality in E-government Websites (Ball-Rokeach \& DeFleur, 1989). Moreover, the IA often provides users with nonspecific stratagem such as querying/searching and navigation/browsing (Jul \& Furnas, 1997). The former assists users in obtaining pertinent information through a search engine while the latter involves orderly movement around the Web environment for users to determine their actions.

\subsection{Accessibility Accommodation}

Specifically vital in the domain of E-government Website Usability, Accessibility is defined as the access to information and functionality (Olalere \& Lazar, 2011; Reis, Barroso, and Goncalves, 2013; Shi, 2007) for users with cognitive or functional limitations (Javahery, Gower, Sinnig \& Forbrig, 2011) through the use of assistive technologies (Desikan \& Ramesh, 2006; Ellcessor, 2016; Jordan, Buranapunsri \& Berge, 2006; Stephanidis, 2009) and step-by-step guidance (Roach \& Cayer, 2010) that facilitates quick navigation through online services and help users overcome problems encountered with E-government Websites (Baker, 2009). Besides, Accessibility radically contributes to user satisfaction in E-government Websites by allowing ease of use and navigability (Pina, Torres, \& Royo, 2010) characterized by searchable databases, and user-friendly layout. This may augment the process-based trust through more frequent usage (Tolbert $\&$ Mossberger, 2006).

\section{OBJECTIVES OF THE STUDY}

In order to constructs Usability as a decisive factor for the continued failure rates of E-government initiatives in developing countries, the prime objective of this paper is:

- To identify variations in Homepage manifestation of desirable features based on specific Usability Heuristics recognized in the Six Dimensional Usability Framework for indicating efforts in alleviating Usability barriers in select E-government Websites.

\section{LITERATURE REVIEW}

Both the digital user needs and the interactive Website design imply a high benefaction by potential users towards the adoption of E-government Websites. Considering this, several researchers have examined Usability issues that plague the adoption of E-government systems, which consequently results in the failure of E-government initiatives especially in developing countries: 
To deem the "other digital divide", the research by Stowers (2002) has significantly contributed to propounding the elements of excellence in E-government Website Usability. The gap was recognized between those who have knowledge about government to obtain immediate gratification through a poorly designed government website and those who have less technology expertise to familiarize themselves with the E-government Websites. This divide yielded the Six-Dimensional Usability through a content analysis of 148 federal websites to facilitate E-government development. The Six elementary Usability features were identified for designing easier to use websites to bridge 'the other divide' and remove Usability barriers. The content analysis of E-government Website Usability recorded data dichotomously based on the presence or absence of particular Usability variables and the evaluated websites were rated based on an additive index of variables.

Furthermore, Baker $(2004,2007,2009)$ meta-analyzed six studies using triangulation method to review each of the Usability dimensions proposed by Stowers (2002) and a coding scheme was developed for an aggregate measurement of discrete variables of manifest content. The proposed methodology demonstrated the efforts taken to encourage Usability and goes beyond the mainstream E-government Website Usability research methodology in terms of scale construction to represent robustness in the qualitative assessment of usefulness of individual Website Usability attributes.

Yahya and Razali (2015) proposed a Usability-based framework for Electronic Government Systems Development that acts as a guideline for government agencies to consider the contributing factors. The authors also defined Usability attributes into six categories namely efficiency, effectiveness, learnability, security, accessibility and usefulness that can be measured during the development process for ensuring the Usability of E-Government systems.

While analyzing the Usability and Accessibility Model for E-Government Websites in Ethiopia, Zeleke (2018) confirmed many usability and accessibility gaps due to underperformance of Usability features of Heuristics rules with non-conformance with W3C, WCAG 2.1 accessibility guidelines. Consideration of users' requirements; improvement in websites' design, functionality, language and services capability; comprehensive websites' content and documentations; augmentation of the capacity and awareness levels of management and employees for the planned implementation of Egovernment website development and assessment activities were suggested.

\section{RESEARCH METHODOLOGY}

An Explanatory Research Design was adopted for a rigorous Usability assessment of 17 E-government Websites using a Usability Measurement Tool (UMT) comprising 14 scale variables with 56 Guttmann scale measures (' 0 ' for absence and '4' for robust manifestation) was developed for examining the intensity of desirable features along a continuum that may enhance E-government Websites’ Usability (Table 1).

Table 1: Guttmann Scale Variables of E-government Websites' Usability

\begin{tabular}{|l|c|c|}
\hline \multicolumn{1}{|c|}{ Usability Dimension } & Scale Variables & Scale Measure \\
\hline Online Services & 3 & 12 \\
\hline User Help and Feedback & 2 & 8 \\
\hline Navigation & 2 & 8 \\
\hline Legitimacy & 3 & 12 \\
\hline Information Architecture & 2 & 8 \\
\hline Accessibility Accommodation & 2 & 8 \\
\hline Total & $\mathbf{1 4}$ & $\mathbf{5 6}$ \\
\hline
\end{tabular}


Six Usability Dimensions with the representation of a set of discrete variables were developed as the mutually exclusive and exhaustive content categories (Chadwick et al., 1984) in the select E-government Websites. The Homepage was assessed with up to the third click for the ordinal distribution of scale variables to explore the manifest content by establishing coding rules to logically categorize each variable for its explicit appearance in each E-government Website.

\section{DATA ANALYSIS}

The obtained data was analyzed using inferential statistical procedures for each of the Six Usability Dimensions with its discrete scale variable set in the select E-government Websites. The Mean Scores were computed for each scale variable using Guttman scale rating that facilitated the computation of the overall Usability Score for each sampled website. Table 2 and Table 3 reveal the results of analysis of paired median differences in Scale Variables using a Related SamplesWilcoxon Signed-Ranks Test that statistically inferred the ordinality within and between each Usability dimension for its Homepage manifestation in select E-government Websites.

Table 2: Showing Results of Wilcoxon Signed Ranked Test for Median Differences Within Scale Variables of Usability Dimensions

\begin{tabular}{|c|c|c|c|c|c|c|c|c|c|}
\hline \multirow[b]{2}{*}{ Scale Variables } & \multicolumn{9}{|c|}{ Wilcoxon Signed Rank Test Within Scale Variables } \\
\hline & $\begin{array}{l}\text { Negative } \\
\text { Ranks }\end{array}$ & $\begin{array}{l}\text { Mean } \\
\text { Rank }\end{array}$ & $\begin{array}{c}\text { Sum } \\
\text { of } \\
\text { Ranks }\end{array}$ & $\begin{array}{c}\text { Positive } \\
\text { Ranks }\end{array}$ & $\begin{array}{l}\text { Mean } \\
\text { Rank }\end{array}$ & $\begin{array}{l}\text { Sum of } \\
\text { Ranks }\end{array}$ & Ties & $\begin{array}{c}Z \\
\text { value }\end{array}$ & $\begin{array}{l}\text { Exact } \\
\text { Sig. }\end{array}$ \\
\hline \multicolumn{10}{|l|}{ Online Service } \\
\hline $\begin{array}{l}\text { Communication } \\
\text { with Officials- } \\
\text { Downloadable } \\
\text { Forms }\end{array}$ & 14 & 8.57 & 120.00 & 3 & 7.50 & 33.00 & 0 & $-2.113^{b}$ & $\mathbf{0 . 0 3 0}$ \\
\hline $\begin{array}{l}\text { Communication } \\
\text { with Officials- } \\
\text { Employment } \\
\text { Information }\end{array}$ & 7 & 9.86 & 69.00 & 8 & 6.38 & 51.00 & 2 & $-0.526^{\mathrm{b}}$ & 0.642 \\
\hline $\begin{array}{l}\text { Downloadable } \\
\text { Forms- } \\
\text { Employment } \\
\text { Information }\end{array}$ & 3 & 7.50 & 22.50 & 10 & 6.85 & 68.50 & 4 & $-1.670^{c}$ & 0.098 \\
\hline \multicolumn{10}{|c|}{ User Help and Feedback } \\
\hline $\begin{array}{l}\text { Search } \\
\text { Functionality- } \\
\text { Foreign Language } \\
\text { Access }\end{array}$ & 15 & 8.77 & 131.50 & 1 & 4.50 & 4.50 & 1 & $-3.380^{b}$ & 0.000 \\
\hline \multicolumn{10}{|l|}{ Navigation } \\
\hline $\begin{array}{l}\text { Link to Other } \\
\text { Agencies- } \\
\text { Broken Links }\end{array}$ & 12 & 8.08 & 97.00 & 2 & 4.00 & 8.00 & 3 & $-2.857^{b}$ & 0.003 \\
\hline \multicolumn{10}{|l|}{ Legitimacy } \\
\hline $\begin{array}{l}\text { Privacy Policy- } \\
\text { Website Security }\end{array}$ & 6 & 7.58 & 45.50 & 6 & 5.42 & 32.50 & 5 & $-0.528^{b}$ & 0.635 \\
\hline $\begin{array}{l}\text { Privacy Policy- } \\
\text { Date of Last Update }\end{array}$ & 9 & 5.00 & 45.00 & 1 & 10.00 & 10.00 & 7 & $-1.852^{b}$ & 0.063 \\
\hline $\begin{array}{l}\text { Website Security- } \\
\text { Date of Last Update }\end{array}$ & 8 & 7.81 & 62.50 & 6 & 7.08 & 42.50 & 3 & $-0.639^{b}$ & 0.566 \\
\hline \multicolumn{10}{|c|}{ Information Architecture } \\
\hline $\begin{array}{l}\text { Audience Focused- } \\
\text { Personalized/Custo } \\
\text { mizable }\end{array}$ & 0 & 0.00 & 0.00 & 12 & 6.50 & 78.00 & 5 & $-3.126^{b}$ & 0.000 \\
\hline
\end{tabular}




\begin{tabular}{|l|c|c|c|c|c|c|c|c|c|}
\hline Accessibility Accommodation \\
\hline $\begin{array}{l}\text { Functional } \\
\text { Accessibility- } \\
\text { Website Readability }\end{array}$ & 0 & 0.00 & 0.00 & 15 & 8.00 & 120.00 & 2 & $-3.542^{\mathrm{b}}$ & $\mathbf{0 . 0 0 0}$ \\
\hline
\end{tabular}

The statistically significant Usability Heuristics are observed for ordinality within Usability dimensions that indicate the robust manifestation of Communication with Officials in 'Online Service' dimension, Search Functionality in 'User Help and Feedback' dimension, Link to Other Agencies in 'Navigation' dimension, Personalized/Customizable features in 'Information Architecture' dimension and Website Readability in 'Accessibility Accommodation' dimension.

Table 3: Showing Results of Wilcoxon Signed Ranked Test for Median Differences Between Scale Variables of Usability Dimensions

\begin{tabular}{|c|c|c|c|c|c|c|c|c|c|}
\hline \multirow[b]{2}{*}{ Scale Variables } & \multicolumn{9}{|c|}{ Wilcoxon Signed Rank Test Between Usability Dimensions } \\
\hline & $\begin{array}{c}\text { Negative } \\
\text { Ranks }\end{array}$ & $\begin{array}{l}\text { Mean } \\
\text { Rank }\end{array}$ & $\begin{array}{l}\text { Sum of } \\
\text { Ranks }\end{array}$ & $\begin{array}{l}\text { Positive } \\
\text { Ranks }\end{array}$ & $\begin{array}{l}\text { Mean } \\
\text { Rank }\end{array}$ & $\begin{array}{l}\text { Sum of } \\
\text { Ranks }\end{array}$ & $\begin{array}{c}\text { Tie } \\
\text { s }\end{array}$ & $\begin{array}{c}\mathrm{Z} \\
\text { value }\end{array}$ & $\begin{array}{l}\text { Exact } \\
\text { Sig. }\end{array}$ \\
\hline \multicolumn{10}{|l|}{ Online Service } \\
\hline $\begin{array}{l}\text { Online Service- User } \\
\text { Help and Feedback }\end{array}$ & 10 & 8.45 & 84.50 & 6 & 8.58 & 51.50 & 1 & $\begin{array}{c}- \\
0.867^{\mathrm{b}}\end{array}$ & 0.416 \\
\hline $\begin{array}{l}\text { Online Service- } \\
\text { Navigation }\end{array}$ & 6 & 9.83 & 59.00 & 11 & 8.55 & 94.00 & 0 & $\begin{array}{c}- \\
0.846^{\mathrm{c}}\end{array}$ & 0.409 \\
\hline $\begin{array}{l}\text { Online Service- } \\
\text { Legitimacy }\end{array}$ & 0 & 0.00 & 0.00 & 16 & 8.50 & 136.00 & 1 & $\begin{array}{c}- \\
3.533^{c} \\
\end{array}$ & 0.000 \\
\hline $\begin{array}{l}\text { Online Service- } \\
\text { Information } \\
\text { Architecture }\end{array}$ & 6 & 6.92 & 41.50 & 10 & 9.45 & 94.50 & 1 & $1.411^{\mathrm{c}}$ & 0.168 \\
\hline $\begin{array}{l}\text { Online Service- } \\
\text { Accessibility } \\
\text { Accommodation }\end{array}$ & 12 & 9.42 & 113.00 & 4 & 5.75 & 23.00 & 1 & $2.379^{\mathrm{b}}$ & 0.018 \\
\hline \multicolumn{10}{|c|}{ User Help and Feedback } \\
\hline $\begin{array}{l}\text { User Help and } \\
\text { Feedback- Navigation }\end{array}$ & 4 & 7.86 & 33.50 & 11 & 8.38 & 86.50 & 2 & $1.526^{\mathrm{c}}$ & 0.139 \\
\hline $\begin{array}{l}\text { User Help and } \\
\text { Feedback- Legitimacy }\end{array}$ & 0 & 0.00 & 0.00 & 17 & 9.00 & 153.00 & 0 & $\begin{array}{c}- \\
3.646^{\mathrm{c}}\end{array}$ & 0.000 \\
\hline $\begin{array}{l}\text { User Help and } \\
\text { Feedback- Information } \\
\text { Architecture }\end{array}$ & 3 & 5.83 & 17.50 & 12 & 8.54 & 102.50 & 2 & $2.452^{c}$ & 0.015 \\
\hline $\begin{array}{l}\text { User Help and } \\
\text { Feedback- } \\
\text { Accessibility } \\
\text { Accommodation }\end{array}$ & 9 & 6.22 & 56.00 & 2 & 5.00 & 10.00 & 6 & $\begin{array}{c}- \\
2.178^{b}\end{array}$ & 0.046 \\
\hline \multicolumn{10}{|l|}{ Navigation } \\
\hline $\begin{array}{l}\text { Navigation- } \\
\text { Legitimacy }\end{array}$ & 0 & 0.00 & 0.00 & 16 & 8.50 & 136.00 & 1 & $\begin{array}{c}- \\
3.541^{\mathrm{c}} \\
\end{array}$ & 0.000 \\
\hline $\begin{array}{l}\text { Navigation- } \\
\text { Information } \\
\text { Architecture }\end{array}$ & 4 & 5.50 & 22.00 & 6 & 5.50 & 33.00 & 7 & $\begin{array}{c}- \\
0.574^{c}\end{array}$ & 0.611 \\
\hline $\begin{array}{l}\text { Navigation- } \\
\text { Accessibility } \\
\text { Accommodation }\end{array}$ & 14 & 9.79 & 137.00 & 3 & 5.33 & 16.00 & 0 & $2.895^{\mathrm{b}}$ & 0.003 \\
\hline \multicolumn{10}{|l|}{ Legitimacy } \\
\hline $\begin{array}{l}\text { Legitimacy- } \\
\text { Information } \\
\text { Architecture }\end{array}$ & 15 & 8.00 & 120.00 & 0 & 0.00 & 0.00 & 2 & $\begin{array}{c}- \\
3.455^{\mathrm{b}}\end{array}$ & 0.000 \\
\hline $\begin{array}{l}\text { Legitimacy- } \\
\text { Accessibility }\end{array}$ & 17 & 9.00 & 153.00 & 0 & 0.00 & 0.00 & 0 & $\begin{array}{c}- \\
3.637^{\mathrm{b}}\end{array}$ & 0.000 \\
\hline
\end{tabular}




\begin{tabular}{|l|c|c|c|c|c|c|c|c|c|}
\hline Accommodation & & & & & & & \\
\hline Information Architecture & & & & & \\
\hline $\begin{array}{l}\text { Information } \\
\begin{array}{l}\text { Architecture- } \\
\text { Accessibility }\end{array}\end{array}$ & 15 & 8.90 & 133.50 & 1 & 2.50 & 2.50 & 1 & $3.428^{\mathrm{b}}$ & $\mathbf{0 . 0 0 0}$ \\
\hline
\end{tabular}

Statistically significant median differences are observed for robust manifestation between ratings of the dimensions 'Legitimacy', 'Accessibility Accommodation', 'Information Architecture' and 'Navigation' than dimensions 'Online Service' and 'User Help and Feedback' on Homepage of sampled E-government Websites.

\section{DISCUSSION}

The present study investigated the E-government efforts in India by evaluating the nature of ordinal distribution of 14 desirable elements for Homepage manifestation in select E-government Websites in India. The study assessed Usability standards for dimensions such as Online Service, User Help and Feedback, Navigation, Legitimacy, Information Architecture and Accessibility Accommodation across 17 E-government Websites of the Executive Branch of the Indian Government using an Expert-based Heuristic Evaluation. One of the noteworthy findings included the inadequacy in the probabilistic manifestation for dimensions namely 'Online Service' and 'User Help and Feedback' across websites. Hence, the distribution of each ordinal variable for its Homepage manifestation across Six Usability Dimensions necessitate designing usable websites for important elements in future.

\section{CONCLUSIONS}

The present study investigated the status of Homepage Usability of select E-government Websites in India for addressing the Low Usability Index as the foremost indicator of failure of E-government initiatives in developing countries. Homepage Usability analyzed for the ordinal distribution of desirable Usability heuristics revealed a consideration of usercentricity for information capacities in these Websites. Hence, web developers and government agencies may augment Content Usability of these Websites in future by utilizing the outcome of the presented dimensional schema of desirable features that construct E-government Website Usability.

\section{REFERENCES}

1. Anderson. (2002). A Usability Analysis of selected Federal Government Web sites. Washington, DC. http://www.aboutweb.org/file/andersen_usb1.pdf

2. Asiimwe, E., and Lim, N. (2010). Usability of Government Websites in Uganda. Electronic Journal of e-Government, 8 (1), 1 12.

3. Awfa Hasan Dakheel \& P. Stanley, “Cloud Based E-Governance Management System”, International Journal of Computer Science Engineering and Information Technology Research (IJCSEITR), Vol. 4, Issue 2, pp, 291-300

4. Baker, D.L. (2004). E-government: Website Usability of the Most Populous Counties. (Unpublished doctoral dissertation, Arizona State University, USA)

5. Baker, D.L. (2007). Website Usability of the Most Populous Counties in the United States. Journal of E-government, 3(3), 6589. DOI: https://doi.org/10.1300/J399v03n03_04

6. Ridhima Jain \& Tarun Shrimali, "E- Janraj- Smart Governance at Municipal Level”, International Journal of Computer Science Engineering and Information Technology Research (IJCSEITR), Vol. 3, Issue 2, pp, 303-316 
7. Baker, D. L. (2009). Advancing E-Government performance in the United States through enhanced Usability benchmarks. Government Information Quarterly, 26(1), 82-88. Available: https://isiarticles.com/bundles/Article/pre/pdf/1306.pdf

8. Fahimeh Babaei Nivlouei, "Explanation of Electronic Synergistic Applications of Human Resource Management According to the E-HRM System”, International Journal of Human Resources Management (IJHRM) ,Vol. 3, Issue 1,pp, 37-50

9. Bishop, S., Shuman, J., \& Vodnik, S. (2015). The Web Collection Revealed Creative Cloud. Boston, MA: Cengage Learning

10. Bouaziz, F. and Fakhfakh, R.(2007). Service Quality in E-government Portals. In Tatnall, A. (Ed.), Encyclopedia of Portal Technologies and Applications (pp.912-7). IGI Global, Hershey, PA.

11. Ajayi, Olusola Olajide \& Ajayi, Olufunke Esther, "E-Learning: A Key to Actualizing Sustainable Educational Development in Africa", International Journal of Computer Science and Engineering (IJCSE) ,Vol. 3, Issue 3,pp, 109-116

12. Cardello, J. (2014). The difference between Information Architecture (IA) and Navigation. https://www.nngroup.com/articles/ia-vs-navigation/

13. Chadwick, B.A., Bahar, H.M. \& Albrecht, S.L. (1984). Content analysis. In B.A.Chadwick et.al. (Ed), Social Science Research Methods (pp. 239-257), New Jersey: Prentice-Hall.

14. Cox, J. and Dale, B.G. (2001). Service quality and E-commerce: An Exploratory Analysis. Managing Service Quality, 11(2), 121-31.

15. DeFleur, M. L., \& Ball-Rokeach, S. J. (1989). Theories of mass communication. New York: Longman

16. Desikan, S., \& Ramesh, G. (2006). Software Testing: Principles and Practice. India: Dorling Kindersley

17. Ellcessor, E. (2016). Restricted Access: Media, Disability, and the Politics of Participation. NY: New York University Press.

18. Huang, Z. and Benyoucef, M., 2014. Usability and Credibility of E-government Websites. Government Information Quarterly, 31(4), 584-595.

19. Javahery, H., Gower, M., Sinnig, D., \& Forbrig, P. (2011). Patterns for Usable Accessible Design. In J.A Jacko (Eds.), Human-Computer Interaction: Design and Development Approaches (pp. 248 -257). Heidelberg: Springer-Verlag.

20. Jordan, R., Buranapunsri, W., \& Berge, Z. (2006). Sustaining Internet Accessibility. In H. Rahman (Ed), Empowering Marginal Communities with Information Networking (pp. 300-317). London: Idea Group Publishing.

21. Jul, S., \& Furnas, G. W. (1997). Navigation in Electronic Worlds: A CHI 97 Workshop Report. SIGCHI Bulletin, 29(4), $44-49$.

22. Kim, M., Kim, J.-H. and Lennon, S. J. (2006) Online Service Attributes Available on Apparel Retail Web Sites: An E-S-QUAL Approach, Managing Service Quality, 16 (1), 51-77.

23. Kim, M. and Stoel, L. (2004). Apparel Retailers: Website quality dimensions and satisfaction, Journal of Retailing and Consumer Services, (2004), Vol. 11, pp.109-117.

24. Koyani (2001). Optimizing the user experience. http://www.usability.gov/pdfs/chapter2.pdf

25. Liu, C. and Arnett, K.P. (2000). Exploring the factors associated with website success in the context of Electronic Commerce, Information and Management, 38(1), 23-33.

26. Mandel, T. (1997). The Elements of User Interface Design. John Wiley \& Sons, Inc, New York.

27. National e-Governance Service Delivery Assessment 2019: e-Governance Landscape-India's Transformative Journey. http://nesda.gov.in/NeSDA_2019_Final_Report.pdf

28. Nielsen, J. (1999) Trust or bust: communicating trustworthiness in web design. www.useit.com/alertbox/990307.htm 
29. Nielsen, J., \& Pernice, K. (2010). Eyetracking Web Usability. Berkeley, CA: New Riders.

30. Nielsen, J. and Tahir, M. (2002), Homepage Usability: 50 WebSites Deconstructed, New Riders Publishing, Indianapolis, IN.

31. Olalere, A., \& Lazar, J. (2011). Accessibility of U.S. federal government home pages: Section 508 compliance and site accessibility statements. Government Information Quarterly,28(3), 303-309. https://doi.org/10.1016/j.giq.2011.02.002

32. Parasuraman, A., Zeithaml, V. A.,\& Malhotra, A.(2005). E-S-QUAL - A multiple-item scale for assessing electronic service quality. Journal of Service Research, 7(X),1-21. http://dx.doi.org/10.1177/1094670504271156.

33. Patterson, K. and Ellis, A. (2004) 'Usability and meeting the needs of educational web site users', Proceedings of the Tenth Australian World Wide Web Conference, Queensland, Australia, 1-13.

34. Pina, V., Torres, L., \& Royo, S. (2010). Is e-government leading to more accountable and transparent local governments? An overall view. Financial Accountability \& Management, 26(1), 3-20.

35. Pirolli, P., \& Card, S. (1999). Information foraging. Psychological Review, 106(4), 643-675.

36. Pirolli, P. (2003). A theory of information scent. In J. Jacko \& C. Stephanidis (Eds.), Human-computer interaction (Vol 1, pp: 213-217). Mahwah, NJ: Lawrence Erlbaum.

37. Reis, A., Barroso, J., \& Goncalves, R. (2013). Supporting accessibility in higher education information systems. In C. Stephanidis, \& M. Antona (Eds.),Universal access in human-computer interaction: Applications and services for quality of life (pp. 250-255). Heidelberg: Springer-Verlag.

38. Sarkar, P. K. and Cybulski, J. L. (2004, June 14-16). Evaluation Of Phenomenological Findings In Is Research: A Study In Developing Web-Based IS. The 12th European Conference in Information Systems (ECIS 2004), Turku, Finland.

39. Shi, Y. (2007). The Accessibility of Chinese Local Government Websites: An Exploratory Study. Government Information Quarterly, 24(2), pp. 377-403.

40. Stephanidis, C. (2009). The Universal Access Handbook. Sound Parkway, NW: CRC Press

41. Stowers, G.N.L. (2002). The State of Federal Websites: The Pursuit of Excellence. Public Administration Programme. San Francisco State University. The PricewaterhouseCoopers Endowment for the Business of Government. http://www.businessofgovernment.org/sites/default/files/FederalWebsites.pdf

42. Tolbert, C. J., \& Mossberger, K. (2006). The Effects of E-Government on Trust and Confidence in Government. Public Administration Review, 66(3), 354-369. http://www.jstor.org/stable/3843917

43. UNESCO (2005). E-government toolkit for developing countries. New Delhi, India: UNESCO Office New Delhi National Informatics Centre (India).

44. United Nations E-Government Survey (2001- 2020). https://publicadministration.un.org/en/Research/UN-e-GovernmentSurveys

45. Venkatesh, V., Hoehle, H., \& Aljafari, R. (2014). A Usability Evaluation of the Obamacare Website. Government Information Quarterly, 31(4), 669-680.

46. Yahya, H and Razali, R. (2015). A Usability-based Framework for Electronic Government Systems Development. ARPN $\begin{array}{llllll}\text { Journal of } \quad \text { Engineering } & \text { Stiences, } & \text { 10(20), } & \text { 9414-9423. }\end{array}$ http://www.arpnjournals.org/jeas/research_papers/rp_2015/jeas_1115_2889.pdf

47. Yang, Z., Cai, S., Zhou, Z. and Zhou, N. (2005). Development and Validation of an Instrument to measure user perceived service quality of information presenting web portals, Information \& Management, 42(4), pp. 575-589. 
48. Zeithaml, Valarie, Parasuraman, Ananthanarayanan, \& Malhotra, Arvind. (2000). E-service quality: definition, dimensions and conceptual model. Marketing Science Institute, Cambridge, MA, Working Paper.

49. Zeleke, Y (2020). Usability and Accessibility Model for E-Government Websites in Ethiopia. African Conference on Information Systems and Technology. 7. https://digitalcommons.kennesaw.edu/acist/2020/allpapers/7. 
